TITLE:

\title{
Expression of cytokines and cytokine receptors in human Schwann cells(Abstract_要旨)
}

\author{
$\operatorname{AUTHOR}(\mathrm{S}):$ \\ Ozaki, Akihiko
}

\section{CITATION:}

Ozaki, Akihiko. Expression of cytokines and cytokine receptors in human Schwann cells 京都大学, 2008, 博士(医学)

\section{ISSUE DATE:}

2008-03-24

URL:

http://hdl.handle.net/2433/135921

RIGHT: 


\begin{tabular}{|c|c|}
\hline 氏 & 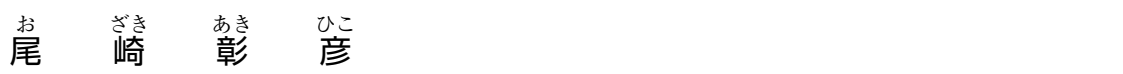 \\
\hline 学位 (専攻分野) & 博 士 (医 学) \\
\hline 学位記 番号 & 論 医 博 第 1948 号 \\
\hline 学位授与の日付 & 平成 20 年 3 月 24 日 \\
\hline 学位授与の要件 & 学 位 規則 第 4 条第 2 項 該 当 \\
\hline 学位論文題目 & $\begin{array}{l}\text { Expression of cytokines and cytokine receptors in human Schwann } \\
\text { cells }\end{array}$ \\
\hline
\end{tabular}

（ヒトシュワン細胞におけるサイトカインとサイトカイン受容体の発現）

論文調査委員 教主授 ${ }^{\text {光 }}$ 山正 雄教授湊長 博教 授 橋本 信 夫

\section{論文内容 の 要旨}

末梢神経は軸索とそれを取り巻く髄鞘から構成されているが, シュワン細胞は髄鞘の形成と維持に関与している。さらに， シュワン細胞は細胞接着因子, 神経栄養因子, サイトカインを分泌し，軸索の伸長，再生に重要な役割を果たしていると考 えられている。実際，慢性炎症性脱髄性多発神経障害（CIDP）ではシュワン細胞が産生する炎症性サイトカインが，髄鞘 や軸索を局所的に障害することが示されている。CIDP患者の末梢神経に浸潤するマクロファージは脱髄や軸索変性を引き 起こすが，シュワン細胞も局所に分泌されたベータ型インターロイキン-1 (IL-1 $\beta$ ), IL-6, アルファ型腫瘍壊死因子 (tumor necrosis factor; TNF- $\alpha$ ) といったサイトカインの分泌を介して病変の進展に寄与する。従来の研究では, ヒト生 検組織におけるサイトカインの検討や挈歯動物由来の培養シュワン細胞の解析はあるが，ヒト初代培養を用いた検討はほぼ 皆無であった。末梢神経障害における病態進展の原因を理解するために，ヒトシュワン細胞におけるサイトカインやサイト カイン受容体の測定系を確立することは重要である。

本研究では, ヒトシュワン細胞を分離, 培養増殖させ, サイトカインとサイトカイン受容体を測定した。ヒト胎児シュワ ン細胞におけるサイトカインとサイトカイン受容体の発現を，逆転写ポリメラーゼ連鎖反応（reverse transcribed polymerase chain reaction; RT-PCR）および酵素結合免疫吸着法（enzyme-linked immunosorbent assay；ELISA）を用 いて測定した。さらに，サイトカインが他のサイトカイン発現に及ぼす影響を検討し，ヒトシュワン細胞のサイトカインネ ットワークを解析した。

ヒトシュワン細胞は, ベータ型インターロイキン1 (interleukin-1 $\beta ; \mathrm{IL}-1 \beta$ ), IL-8, IL-11, IL-12, IL-15, ベータ型ト ランスフォーミング増殖因子（transforming growth factor, TGF- $\beta$ ） のメッセンジャーRNA (messenger ribonucleic acid; mRNA）を発現していた。また, IL-1, IL-4, IL-6, IL-8, IL-13, 腫瘍壊死因子（tumor necrosis factor; TNF）に 対する受容体，およびサイトカイン受容体サブユニットのひとつである gp130を恒常的に発現していた。IL-1 $\beta$ やTGF- $\beta$ により，ヒトシュワン細胞におけるIL-1 $\beta$, IL-6, IL-15mRNAの発現は充進した。ELISAによる検討では，IL-6の蛋白 生成はIL-1 $\beta$ により㠵進し，ガンマ型インターフェロン（interferon- $\gamma$; IFN- $\gamma$ ）により抑制された。以上の結果より，末 梢神経の障害部位においてヒトシュワン細胞はサイトカインに反応し, 自らもサイトカインを分泌することで白血球遊走や 軸索障害の増悪に関わり，病的状態を修飾することが示唆された。

\section{論 文 審 査 の 結 果 の 要 旨}

軸索切断, ギラン・バレー症候群などの末梢神経疾患では, 炎症誘発性サイトカインが発現し, マクロファージやT細胞 が神経障害の進展に寄与することが知られている。しかしシュワン細胞の炎症病態への関与は, 特にヒトでは不明な点が多 い。そこで, ヒト胎児シュワン細胞を分離培養し, 増殖因子を用いて高密度のシュワン細胞培養系を作製した。発現するサ イトカインとその受容体を，逆転写ポリメラーゼ連鎖反応，および酵素結合免疫吸着法を用いて測定した。 
ヒトシュワン細胞は, サイトカインとその受容体を発現し, サイトカインでは炎症誘発性と抗炎症性サイトカインの両者 を発現していた。 $\beta$ 型インターロイキン-1（IL-1 $\beta$ ）刺激により IL-1 $\beta$ 発現は増加し, positive feedbackを形成して炎症 が増強される可能性が示された。また, IL- $1 \beta$ その他のサイトカイン刺激により, IL-6の増加, IL-12, IL-15の減少が認 められ，Th1/2 バランスを Th2 優位に誘導することから過剰な自己免疫反応が抑制されることが示唆された。一方， $\gamma$ 型 インターフェロン $(\mathrm{IFN}-\gamma)$ 刺激により, サイトカイン mRNA 発現と蛋白分泌には乘離がみられ, サイトカインの発現調 節は転写後にも行われることが示唆された。

以上の研究は, サイトカインネットワークにおけるヒトシュワン細胞の機能の解明に貢献し, 末梢神経疾患の炎症制御機 構の理解に寄与するところが多い。

したがって，本論文は博士（医学）の学位論文として価値あるものとみとめる。

なお，本学位授与申請者は，平成20年 1 月 7 日実施の論文内容とそれに関連した試問を受け，合格と認められたものであ る。 